\title{
PERSEPSI WISATAWAN LANJUT USIA PADA FASILITAS AKOMODASI DAN AKTIVITAS PARIWISATA BERNUANSA SENI BUDAYA DI DESA SANUR
}

\author{
Yayu Indrawati ${ }^{1}$
}

\begin{abstract}
The aim of this research is to identify elder tourist perception toward accommodation facilities and tourism activities from art and cultural atmosphere point of view in Sanur Village. This research uses various approaches such as social and cultural, social exchange theory. This study took 50 (fifty) respondents, and they were used as sample using "proportional stratified random sampling". Respondents were taken from elder tourist aged above 60 (sixty) years old comes from Australia, Nederland, German, United Kingdom and Japan. Data are taken by observation, interview, questioner and documentation. Silver age tourist's perception is analyzed by Likert Scale and employed descriptive analysis method. The study shows that generally silver age tourist perception toward accommodation facilities is positive with average score $89.07 \%$. Besides accommodation facilities it is also has activities related to fulfillment of physical need such as attending cultural events, exercises, hobbies and leisure.
\end{abstract}

Keywords: elder tourist, accommodation facilities, and art

${ }^{1}$ Yayu Indrawati adalah Dosen Universitas Nusa Cendana Kupang 


\section{Persepsi Wisatawan Lanjut Usia... (Yayu Indrawati)}

Pariwisata telah menjadi bagian dari kehidupan masyarakat Bali dan memberikan kontribusi besar dalam pembangunan. Pada tahun 2006 distribusi PDRB masih di dominasi oleh sektor-sektor yang bergerak di bidang pariwisata khususnya restoran, perhotelan dan perdagangan memberikan kontribusi sebesar (30,92\%) sektor pertanian (21,52\%) dan sektor jasa (13,63\%).

Wisatawan datang ke Bali dengan berbagai latar belakang tujuan, diantaranya untuk menikmati berbagai bentuk seni dan kebudayaan yang dimilikinya. Seperti yang dikemukakan oleh Shaw dan Williams dalam Ardika (2003) dari 10 elemen budaya yang menjadi daya tarik wisatawan yakni: (a) kerajinan, (b) tradisi, (c) sejarah dari suatu tempat/daerah, (d) arsitektur, (e) makanan lokal/tradisional, (f) seni dan musik, (g) cara hidup suatu masyarakat, (h) agama, (i) bahasa, dan (j) pakaian lokal/ tradisional. Elemen budaya tersebut sangat sesuai dengan jenis kepariwisataan yang dikembangkan di Bali yaitu pariwisata budaya.

Dalam perkembangannya terdapat perubahan trend dalam dunia pariwisata. Era memasarkan pariwisata dengan harapan mendapat kunjungan wisatawan dalam jumlah yang besar ke suatu daerah tujuan wisata telah ditinggalkan. Selain jumlah kedatangan wisatawan sebagai indikator perkembangan pariwisata tolok ukur lainnya adalah peningkatan kualitas wisatawan. Hal ini sangat sesuai dengan visi yang dikembangkan oleh Dinas Pariwisata Propinsi Bali dalam pembangunan pariwisata yaitu: “Terwujudnya pariwisata budaya yang berkualitas dan berkelanjutan, berdasarkan Tri Hita Karana, berdaya saing global serta dapat meningkatkan kesejahteraan masyarakat lokal”. Menurut Pitana (2002) wisatawan berkualitas memiliki ciri-ciri: (a). Memiliki pengeluaran yang tinggi (high spending power ) termasuk pengeluaran per hari dan lama tinggal di suatu destinasi; (b). Menghormati budaya serta masyarakat lokal (appreciation to local culture; dan (c). Menghormati lingkungan (appreciation to environment ).

Dilihat dari segi usia wisatawan yang beragam Pasar orang tua atau senior market merupakan kelompok penting karena besarnya pasar dan potensialnya untuk berkembang. Dengan kemajuan teknologi, sistem kesehatan dan semakin panjang jangka waktu hidup seseorang secara langsung meningkatkan jumlah penduduk lanjut usia. Pada fase ini orang tua telah ditinggalkan oleh anak-anaknya untuk hidup mandiri. Kelompok usia ini dikenal dengan istilah DINKS (Double Income No Kids). Waktu luang yang dimiliki sangat besar sehingga memungkinkan 
mereka untuk tinggal di suatu destinasi lebih lama. Pada umumnya dengan sistem pensiun yang baik mereka mapan secara finansial. Untuk mengantisipasi kecenderungan pasar di masa depan yaitu semakin banyaknya konsumen wisatawan lanjut usia yang berlibur di Bali maka Pemerintah RI menetapkan suatu kebijakan bagi wisatawan lanjut usia yaitu dengan mengijinkan wisatawan lanjut usia untuk tinggal lebih lama di Indonesia. Kelompok wisatawan ini diijinkan untuk tinggal di Indonesia selama 1 tahun. Kebijakan tersebut telah dituangkan dalam SK Menteri Kehakiman No. M-04-12.01.02/1998. Surat keputusan ini dibuat berdasarkan Keputusan Presiden/Keppres No. 31/1998. SK Menteri Kehakiman di atas kemudian ditindaklanjuti dengan keluarnya Ketetapan Dirjen Imigrasi No. F.256-12.02/2000. Ketetapan ini menyatakan bahwa wisatawan lanjut usia dapat diberikan Temporary Visa sebagai penduduk sementara selama 1 tahun dan dapat diperpanjang sampai 5 tahun. Visa ini hanya berlaku bagi negara-negara Eropa, Amerika, Amerika, Kanada, Jepang, Asean, Australia dan Selandia Baru.

Wisatawan mancanegara yang berkunjung ke Bali menyebar ke seluruh daerah wisata di Bali. Menyadari akan daya tariknya sebagai suatu destinasi wisata maka pemerintah menganggap perlu dibuatnya kawasan-kawasan pariwisata mengingat Bali terdiri dari 9 (Sembilan) Kabupaten/Kota (8 Kabupaten dan 1 Kota) untuk mempermudah dalam pengaturan dan pengawasannya serta dalam upaya untuk memanfaatkan potensi yang ada di setiap daerah maka dikeluarkan peraturan yaitu Peraturan Daerah Nomor 3 tahun 2005 tentang Perubahan Tata Ruang Wilayah Propinsi Bali, menetapkan 15 kawasan pariwisata ditambah dengan 6 ( enam ) Objek dan Daya Tarik Wisata Khusus (Kintamani, Bedugul/Pancasari, Tanah Lot, Air Sanih,Palasari dan Gilimanuk ). Salah satu dari 15 kawasan pariwisata tersebut adalah kawasan pariwisata Sanur. Sanur merupakan salah satu kawasan pariwisata tertua di Bali dan mulai berkembang sejak dibangunnya Hotel Bali Beach oleh Presiden Soekarno pada tahun 1963. Letaknya yang strategis di tepi jalan By Pass regional, hanya sekitar 20 menit dari Bandara Internasional Ngurah Rai dan dekat dengan pusat kota. Sanur merupakan kawasan waterfront dengan garis pantai mencapai 9 kilometer mulai pantai Padanggalak hingga Mertesari. Daya tarik utama di samping budaya yang dimiliki adalah panorama alam yang indah, pantai yang berpasir putih sangat diminati oleh wisatawan mancanegara dari berbagai macam usia. Pantai ini sangat penting nilainya bagi keberlanjutan berbagai 


\section{Persepsi Wisatawan Lanjut Usia... (Yayu Indrawati)}

aktivitas sosial lainnya seperti agama dan budaya. Di kawasan ini juga wisatawan bisa menikmati terbitnya matahari di pagi hari. Selain pantai, wisatawan juga bisa menikmati suasana yang masih sangat asri di Sanur, jalan yang tertata dengan rapi, lingkungan yang relative masih alami, tempat suci/pura sebagai daya tarik wisata, pertunjukan seni dan budaya, tradisi masyarakat, museum, gallery dan fasilitas lainnya sebagai pendukung kegiatan pariwisata

Untuk mendukung Sanur sebagai daerah tujuan wisata (DTW) maka dibangunlah berbagai macam fasilitas pariwisata baik itu fasilitas pokok, penunjang, maupun fasilitas pelengkap pariwisata. Fasilitas akomodasi seperti hotel yang ada di Desa Sanur, mulai dari hotel baik bintang maupun non bintang, villa, bungalow dan lainnya di Sanur sebagian besar terletak di dekat pantai dan memiliki akses yang sangat dekat dengan pantai menjadi salah satu daya tarik bagi wisatawan lanjut usia untuk menginap di daerah ini.

Fasilitas akomodasi dan aktivitas pariwisata yang ditawarkan di Desa Sanur terkait dengan seni dan budaya yang dimiliki oleh masyarakat Bali, seperti akomodasi yang bercorak tradisional Bali dilihat dari segi arsitekur, penggunaan material khas Bali seperti batu-batu alam, ukiran, barang kerajinan seperti kursi-kursi rotan dan beragam hasil kerajinan masyarakat Bali, penataan taman-taman tropis yang ada di sekitar fasilitas akomodasi juga sangat disesuaikan dengan konsep budaya Bali. Kemudian aktivitas wisata yang terdapat di Desa Sanur juga sangat bervariasi dan menurut hasil penelitian,tradisi masyarakat Sanur merupakan komponen budaya yang paling diminati oleh wisatawan (Ardika, 2003: 18).

Dilihat dari segi usia, wisatawan yang datang ke Desa Sanur sangat beragam tingkatan umurnya. Sebagian besar wisatawan tersebut berusia lanjut dan berasal dari kawasan Eropa, seperti Inggris, Jerman dan Belanda. Terdapat juga wisatawan yang berasal dari kawasan Asia Pasifik misalnya Jepang dan Australia. Empat negara tersebut kecuali Belanda masuk dalam 10 (sepuluh) besar negara yang mendatangkan wisatawan terbanyak ke Bali.

Sebagian besar wisatawan lanjut usia yang berkunjung ke Desa Sanur karena memiliki kenangan tersendiri terhadap daerah ini, disamping itu juga mereka sangat menyukai budaya dan tradisi masyarakat setempat serta keramahtamahan penduduknya. Selama berada di destinasi terdapat berbagai aktivitas pariwisata yang dilakukan 
terutama merupakan wisata tirta (swimming, boating, canoeing), dan aktivitas yang dilakukan di darat seperti menghadiri kegiatan - kegiatan kebudayaan, seperti Sanur Village Festival dan Kite Festival, dan atraksi budaya lainnya, relaksasi, jogging, spa dan lainnya. Aktivitas yang dilakukan berkaitan dengan pemenuhan hobi dan pemenuhan kebutuhan fisik. Dari latar belakang tersebut penulis memandang perlu untuk melakukan penelitian mengenai persepsi wisatawan lanjut usia terhadap fasilitas akomodasi dan aktivitas pariwisata bernuansa seni budaya di Desa Sanur.

Penelitian yang dilakukan ini bersifat deskriptif yaitu suatu metode yang digunakan untuk mendapatkan gambaran dari tujuan penelitian. Untuk menganalisis tanggapan wisatawan digunakan Skala Likert yang merupakan alat untuk mengukur sikap dari keadaan yang sangat positif ke jenjang yang sangat negatif. Data yang telah terkumpul dari hasil penelitian di lapangan akan diklasifikasikan untuk melihat persepsi wisatawan lanjut usia terhadap fasilitas akomodasi dan aktivitas pariwisata bernuansa seni budaya di Desa Sanur.

Lokasi penelitian adalah Desa Sanur Kota Denpasar. Pemilihan lokasi ini didasarkan pada pertimbangan yaitu: (a) Sanur merupakan daerah tujuan wisata yang cukup banyak diminati oleh wisatawan mancanegara dan nusantara; (b) fasilitas akomodasi yang ditawarkan beragam bentuknya mulai dari villa dan bungalow hingga kamar yang teletak di bangunan blok hotel, akomodasi tersebut memiliki ciri khas tradisional Bali dan (c) aktivitas wisata yang ditawarkan beragam, mulai aktivitas wisata tirta hingga wisata darat.

\section{TINJAUAN PUSTAKA}

\section{Pariwisata}

Pengertian pariwisata berdasarkan Undang-Undang RI No. 9 Tahun 1990 tentang kepariwisataan adalah segala sesuatu yang berhubungan dengan wisata, termasuk pengusahaan objek dan daya tarik wisata serta usaha-usaha terkait di bidang tersebut. Objek dan daya tarik wisata adalah sebagai berikut: (a) objek dan daya tarik wisata ciptaan Tuhan yang berwujud keadaan alam serta flora dan fauna; (b) objek dan daya tarik hasil karya manusia yang berwujud museum peninggalan sejarah, seni budaya, agro wisata, wisata tirta, wisata buru, wisata petualangan alam, taman rekreasi dan lain-lain. 


\section{Persepsi Wisatawan Lanjut Usia... (Yayu Indrawati)}

Pariwisata (tourism) secara sederhana adalah suatu perjalanan untuk bersenang senang (Yoeti, 2001: xx). Lebih lanjut dijelaskan bahwa ada empat kriteria yang harus dipenuhi untuk menyatakan perjalan yang dilakukan oleh seseorang adalah perjalanan wisata, yaitu: (a) perjalanan itu semata-mata untuk bersenang-senang; (b) perjalanan itu harus dilakukan dari suatu tempat (dimana orang itu tinggal) ke tempat lain yang bukan kota atau Negara dimana ia biasanya tinggal; (c) perjalanan dilakukan dalam waktu minimal dua puluh empat jam, dan (d) perjalanan yang dilakukan tidak ada kaitannya dengan kegiatan mencarai nafkah. Mereka melakukan perjalanan semata-mata sebagai konsumen di tempat yang dikunjunginya.

Menurut Hunzieker dan Kraft (Yoeti, 2001: xxii), pariwisata didefinisikan sebagai total keseluruhan dari hubungan - hubungan dan gejala yang timbul dari perjalanan dan pendiaman orang - orang asing sepanjang pendiaman itu tidak bermaksud menjadi penduduk yang menetap dan tidak ada kaitannya dengan kegiatan mencari nafkah di tempat yang dikunjungi.

Ada tiga kriteria yang harus dipenuhi dalam pengertian perjalanan yang termasuk dalam kategori pariwisata, yaitu: (a) terjadi perpindahan antara dua tempat atau lebih ( movement between two or more places or origin and destination); (b) maksud kunjungan untuk bersenang-senang (purposes of travel for pleasure); dan (c) perjalanan itu dilakukan untuk sementara waktu (temporary). Sedangkan menurut umur yang melakukan perjalanan; pariwisata dibagi menjadi 2 jenis yaitu: (a) Youth Tourism (pariwisata remaja); jenis kepariwisataan yang dikembangkan bagi para remaja yang suka melakukan perjalanan wisata dengan harga yang relative murah; dan (b) Adult Tourism, yaitu kegiatan pariwisata yang diikuti oleh orang-orang yang berusia lanjut. Biasanya orang-orang yang sedang menjalani masa pensiun dan ingin menghabiskan masa tuanya dengan melihat negara lain yang belum pernah dikunjunginya (Yoeti, 2001: 119).

Smith (1997: 124-125) mengelompokkan wisatawan atas dasar pengaruh sosial dan ekonomi yang ditimbulkan terhadap masyarakat lokal, daerah tujuan wisata, norma-norma yang berlaku menjadi tujuh kategori, sebagai berikut

1) Explorer-type tourist, wisatawan yang bertujuan untuk menemukan sesuatu yang terkait dengan ilmu pengetahuan. Jumlah wisatawan 
yang tergolong dalam tipe ini sangat sedikit dan mereka melakukan kontak yang intensif dengan masyarakat setempat.

2) Elite tourist, kelompok wisatawan kaya yang banyak melakukan kegiatan berbelanja. Mereka biasanya menggunakan jasa biro perjalanan dan ditemani oleh seorang pemandu. Wisatawan jenis ini mempunyai lama tinggal yang relative singkat.

3) Off-beat tourist, wisatawan petualang yang bertujuan untuk mencari tempat-tempat yang sepi dan jauh dari pusat keramaian, misalnya mengikuti acara hunting safari.

4) Unusual tourist, wisatawan yang melakukan perjalanan sehari (one day package tour) untuk mengunjungi tempat-tempat yang primitive dan mengamati budaya yang masih asli.

5) Incipient mass tourist, wisatawan yang melakukan perjalanan dalam kelompok (group) kecil dengan menggunakan bus wisata dan menginap pada hotel berbintang. Mereka sering melakukan keluhan (complaint) apabila pelayanan yang diberikan kurang memuaskan.

6) Mass tourist, wisatawan yang tergolong dalam tipe ini melakukan perjalanan wisata secara kontinyu sepanjang tahun. Mereka tergolong orang kelas menegah dan biasanya menginap pada hotel kecil. Jumlah wisatawan jenis ini sangat banyak dengan tinggal di daerah tujuan wisata beberapa minggu.

7) Charter tourist, kelompok wisatawan ini menginginkan kawasan yang maju dan cosmopolitan dengan berbagai fasilitas yang lengkap sesuai dengan kebutuhannya. Biasanya mereka menggunakan hari liburnya pada akhir pekan untuk menikmati kenyamanan dan keindahan lingkungan.

Menurut Butler (1996: 97) pola perilaku wisatawan saat ini, melakukan perjalanan ke lokasi yang berbeda dan eksotik (bagi mereka), dengan tujuan khusus seperti mempelajari budaya, bahasa, perilaku, adat istiadat. Transfer budaya adalah hal khusus dan juga merupakan sebagian harapan mereka dalam melakukan perjalanannya.

\section{Fasilitas Akomodasi}

Berdasarkan Brittanica Encyclopedia dalam http://www. answers.com/topic/accomodations yang dapat dikategorikan fasilitas akomodasi adalah: (a) room and board, lodging; dan (b) a seat, 
compartiment, or room on public vehicle. Sedangkan dalam pengertian umum fasilitas akomodasi di dalamnya menyangkut hotel, penginapan, villa, peristirahatan, bungalow, homestay dan sebagainya. Semua jenis akomodasi dibangun sebagai tempat beristirahat para wisatawan selama berada di Tourist Destination Area. Fasilitas akomodasi merupakan salah satu bentuk sarana pokok kepariwisataan khususnya dalam bidang residential tourist plan yaitu perusahaan yang memberikan pelayanan untuk menginap bagi wisatawan.

\section{Akivitas Pariwisata}

Aktivitas wisata adalah suatu kegiatan yang dilakukan oleh wisatawan ketika mereka berlibur di suatu destinasi. Aktivitas atau kegiatan tersebut secara partisipatif diikuti oleh wisatawan. Aktivitas pariwisata banyak dilakukan di daerah pegunungan atau pedesaan ataupun di daerah pinggir laut. Lokasi aktivitas tersebut berhubungan dengan lingkungan alam maupun sumber daya alam.

Terdapat berbagai bentuk aktivitas wisata yang bisa dilakukan oleh wisatawan, kegiatan yang dilakukan tersebut didorong oleh motivasi dan hobi wisatawan itu sendiri. Berbagai macam aktivitas tersebut dilakukan untuk mengisi rentang waktu liburan sehingga wisatawan tidak akan merasa bosan selama liburannya. Aktivitas wisata yang dilakukan berkaitan dengan pemenuhan hobi dan penyegaran fisik serta mental. Kegiatan-kegiatan wisata banyak bentuk dan ragamnya, ada yang memerlukan peralatan khusus, pengetahuan dan keahlian tertentu, seperti misalnya rafting, climbing, diving, bird watching dan masih banyak lainnya.Tetapi ada juga yang tidak memerlukan keahlian serta pengetahuan khusus seperti misalnya jogging, cycling, seeightseeing, attending cultural events dan lainnya.

\section{Seni Budaya}

Menurut Koentjaraningrat (1990) setiap kebudayaan suku bangsa di dunia memiliki tujuh unsur kebudayaan yang universal yaitu: (a) bahasa; (b) sistem pengetahuan; (c) organisasi sosial; (d) sistem peralatan hidup dan teknologi; (e) sistem mata pencaharian hidup; (f) sistem religi; dan (g) kesenian. Kesenian adalah merupakan salah satu dari tujuh unsur kebudayaan yang universal tersebut, oleh karena itu seni atau kesenian merupakan produk dari sebuah kebudayaan dari setiap suku atau bangsa 
di dunia. Untuk memahami sebuah fenomena seni tidak bisa dipisahkan dari latar belakang dimana seni itu lahir.

\section{FASILITAS AKOMODASI DAN AKTIVITAS PARIWISATA DI DESA SANUR}

Desa Sanur merupakan bagian Wilayah Kecamatan Denpasar Selatan, Kota Denpasar Provinsi Bali dengan luas wilayah keseluruhan 402 Ha. Desa Sanur merupakan dataran rendah wilayah pantai dengan ketinggian di bawah 500 meter, di atas permukaan laut dengan kemiringan (0 meter). Suhu udara rata-rata berkisar antara 28 - 30 o C. Daerah pesisir pada umumnya mempunyai jumlah curah hujan tahunan yaitu kurang dari $2000 \mathrm{~mm}$. Keadaan tanah cukup subur namun karena Sanur merupakan daerah pengembangan pariwisata, maka sebagian besar tanah digunakan untuk daerah pemukiman, bangunan jasa pariwisata dan sedikit dipergunakan sebagai lahan pertanian. Seperti halnya daerah lain di Bali yang pada umumnya mengalami dua kali perubahan musim/ iklim yaitu musim hujan dan musim kemarau (iklim tropis) demikian juga halnya dengan Kelurahan Sanur yang mempunyai iklim yang sama. (Monografi Sanur, 2000).

Batas Desa Sanur Kecamatan Denpasar Selatan, Kotamadya Denpasar, Propinsi Daerah Tk. I Bali adalah: sebelah Utara Desa Sanur Kaja, sebelah Timur Selat Lombok, sebelah Selatan Samudra Indonesia, sebelah Barat Desa Sanur Kauh. Di Desa Sanur, terdapat berbagai macam fasilitas akomodasi yang beragam jenis dan macamnya, mulai dari kamar hotel dalam bentuk blok (building), villa, bungalow, guest house, homestay dan lainnya. Secara keseluruhan jumlah fasilitas akomodasi yang ada di Desa Sanur adalah sebagai berikut:

Tabel 1. Jumlah Fasilitas Akomodasi di Desa Sanur

\begin{tabular}{|r|l|r|}
\hline No. & \multicolumn{1}{|c|}{ Jenis Fasilitas Pariwisata } & Jumlah \\
\hline \multirow{2}{*}{1.} & Akomodasi & \\
& Hotel berbintang (1-5) & 21 \\
& Hotel Melati & 66 \\
& Pondok Wisata & 27 \\
\hline & Jumlah & 114 \\
\hline
\end{tabular}

Sumber: Dinas Pariwisata Kota Denpasar Tahun 2007 


\section{Persepsi Wisatawan Lanjut Usia... (Yayu Indrawati)}

Lokasi fasilitas akomodasi mulai dari hotel berbintang sampai non bintang, villa, bungalow dan lainnya di Sanur sebagian besar terletak di dekat pantai dan memiliki akses yang sangat dekat dengan pantai menjadi salah satu daya tarik bagi wisatawan lanjut usia untuk menginap di daerah ini.

Struktur bangunan akomodasi tersebut juga terdiri dari bangunanbangunan yang menyerupai villa atau bungalow sehingga tidak akan menyulitkan bagi wisatawan khususnya wisatawan lanjut usia untuk menggunakan fasilitas tersebut. Disamping itu juga kondisi lingkungan yang lebih sepi dibandingkan dengan destinasi lain seperti Kuta dan Nusa Dua cenderung membuat wisatawan lanjut usia lebih memilih Sanur sebagai tempat untuk berlibur.

Fasilitas akomodasi tersebut juga sangat memperhatikan penggunaan- penggunaan material lokal dan barang-barang kerajinan lokal yang ditempatkan di berbagai sudut baik ruangan kamar, lobby, restoran yang terdapat dalam hotel dan di berbagai tempat lainnya untuk menambah nuansa budaya lokal sebagai daya tarik utama fasilitas akomodasi tersebut.

Selain fasilitas akomodasi juga terdapat kegiatan yang dapat dilakukan oleh wisatawan lanjut usia ketika berlibur di Desa Sanur. Aktivitas tersebut dilakukan selama rentang masa liburan. Aktivitas tersebut berkaitan dengan pemenuhan kebutuhan fisik seperti berolah raga, menyalurkan hobby seperti melihat kegiatan budaya yang sedang berlangsung misalnya menyaksikan rangkaian tradisi masyarakat dalam melaksanakan upacara adat, melihat Sanur Village Festival, Kite Festival yang secara teratur di selenggarakan masyarakat desa Sanur, mengikuti kelas spa atau pun mengikuti kelas memasak yang diselenggarakan di hotel tempat wisatawan menginap.

Dengan keadaan lingkungan yang lebih tenang dibandingkan dengan destinasi lain seperti Kuta, Desa Sanur merupakan tempat yang tepat bagi wisatawan lanjut usia untuk melakukan berbagai aktivitas pariwisata yang berkaitan dengan seni, budaya, tradisi masyarakat setempat.

Aktivitas terkait dengan kebutuhan yang di dorong oleh motivasi

fisik wisatawan lanjut usia diantaranya adalah relaksasi, berlari pagi, bersepeda, jalan-jalan dan spa. Kemudian aktivitas lain yang berhubungan dengan pemenuhan hobi dan kesenangan serta di picu oleh 
motivasi pribadi dan motivasi peningkatan kemampuan diantaranya adalah visiting friends and relatives, mengikuti kelas memasak, berpartisipasi pada kelas yoga, mengikuti kelas spa, membaca, seeightseeing, shopping dan menghadiri festival atau kegiatan kebudayaan seperti Sanur Village Festival, Kite Festival yang diselenggarakan secara teratur setiap tahunnya.

\section{PERSEPSI WISATAWAN LANJUT USIA TERHADAPFASILITAS AKOMODASI DAN AKTIVITAS PARIWISATA BERNUANSA SENI BUDAYA}

Responden yang ditetapkan untuk menilai fasilitas akomodasi di Desa Sanur adalah wisatawan mancanegara yang sedang berkunjung di Desa Sanur dan mereka menikmati fasilitas akomodasi tersebut. Secara umum wisatawan yang datang dan menginap di Desa Sanur adalah pasangan yang berusia lanjut dan ada pula yang berlibur bersama keluarga dan anak-anak mereka. Kedatangan mereka untuk berlibur disertai dengan keinginan berelaksasi dan menikmati fasilitas akomodasi yang tersedia.

Dalam pemilihan fasilitas akomodasi mereka cenderung untuk menginap di hotel maupun villa yang memiliki akses langsung ke pantai ataupun berlokasi dekat dengan pantai. Pemilihan lokasi akomodasi tersebut dilakukan agar wisatawan dapat dengan mudah mencapai pantai dan bisa melakukan aktivitas bersantai, seperti berjemur, lari pagi tanpa harus berputar mencari jalan menuju pantai.

Keberadaan wisatawan lanjut usia di Desa Sanur telah menimbulkan suatu proses sosial budaya. Proses tersebut terwujud dalam interaksi yang dilakukan secara timbal balik oleh masing- masing aktor dalam hal ini wisatawan lanjut usia dan masyarakat khususnya karyawan sebagai penyedia fasilitas pariwisata

Sebagai suatu arena perjumpaan sosial maka, pariwisata merupakan arena interaksi yang di dalamnya terjadi pertukaran sumber daya antar individu. Wisatawan lanjut usia yang datang berlibur di Desa Sanur mengeluarkan sejumlah uang dengan harapan dapat menikmati fasilitas akomodasi dan aktivitas pariwisata bernuansa seni budaya yang tersedia, sesuai dengan inti teori pertukaran sosial yang menyatakan bahwa teori pertukaran merupakan proses transaksi dan respon yang 
diharapkan adalah reward berupa pelayanan maksimal, kualitas produk yang baik seperti akomodasi yang nyaman. Wisatawan lanjut usia menyatakan bahwa fasilitas akomodasi dapat memberikan suatu kenyamanan baik dari segi suasana kamar dengan penataaan yang apik, disain kamar yang sangat kental nuansa lokal serta penggunaan barangbarang kerajinan lokal sebagai bahan utama penataan kamar, keamanan yang ada di sekitar hotel kemudian keberadaan taman-taman serta jarak antar fasilitas yang satu dengan lainnya dalam areal hotel. Semuanya menjadi satu kesatuan yang menyeluruh sehingga wisatawan lanjut usia merasa nyaman karena tidak menemukan kesulitan yang berarti ketika menikmati fasilitas akomodasi. Jarak antara fasilitas akomodasi dengan pantai juga tidak terlalu jauh sehingga akan memudahkan wisatawan lanjut usia jika ingin melakukan aktivitas di pinggir pantai. Kemampuan bahasa asing dari karyawan hotel juga mendapat penilaian karena walaupun fasilitas akomodasi yang diberikan sudah baik tetapi jika terdapat kendala dalam pelayanan karena keterbatasan bahasa yang dimiliki maka fasilitas yang baik tidak akan berarti banyak.

Wisatawan lanjut usia umumnya cenderung memilih lokasi kamar yang terletak di lantai bawah baik pada hotel building maupun bungalow. Kecermatan karyawan dalam hal ini receptionist dalam memilih kamar bagi wisatawan lanjut usia juga sangat penting mengingat keterbatasan fisik wisatawan ini.

Tabel 2. Persepsi Wisatawan Lanjut Usia terhadap Fasilitas Akomodasi

\begin{tabular}{|l|c|}
\hline Persepsi Wisatawan Lansia & Persentase ( \% ) \\
\hline Atmosfir tradisional akomodasi & 85.60 \\
Penggunaan bahan kerajinan lokal & 92.60 \\
Keamanan & 90.80 \\
Penataan taman di areal akomodasi & 92.00 \\
Jarak internal fasilitas akomodasi & 87.60 \\
Kemampuan bahasa asing staf hotel & 89.60 \\
\hline Rata - rata & $\mathbf{8 9 . 0 7}$ \\
\hline
\end{tabular}

Sumber: Hasil olah data 
Dilihat dari Tabel 2. penilaian positif wisatawan lanjut usia terhadap fasilitas akomodasi mendapat rata-rata skor sebanyak $89.07 \%$ yang artinya sangat baik. Khusus bagi variabel penggunaan bahan kerajinan lokal yang mendapatkan skor tertinggi yaitu (92.60\%) menegaskan bahwa elemen-elemen tradisional yang dipergunakan baik pada fasilitas akomodasi dan fasilitas lainnya sangat mendukung terciptanya suatu nuansa yang berbau khas lokal. Dari dekorasi yang dipilih tingkat kecenderunganya hampir semua memakai wujud benda budaya hasil kerajinan masyarakat lokal (Bali). Penggunaan unsur lokal yang dipilih seperti batu-batu alam, kayu untuk flafon, ukiran dinding kamar atupun di lobby, pada elemen bagunan kamar sangat sesuai dengan pemilihan bahan kerajinan yang dipergunakan seperti meja rotan /kayu, kursi rotan/kayu, lukisan, pernak-pernik keramik lokal, patung yang sangat berciri khas Bali, hal ini diharapkan sebagai usaha menampilkan suasana tradisional lokal. Dengan adanya pariwisata, maka permintaan akan barang-barang kerajinan khas Bali akan terus mengalami peningkatan, baik sebagai bahan eksport maupun penggunaan untuk kepentingan interior yang akan menambah nuansa ke-Bali-annya.

Selain fasilitas akomodasi yang kental dengan nuansa seni budaya lokal juga terdapat kegiatan yang dapat dilakukan oleh wisatawan lanjut usia ketika berlibur di Desa Sanur. Aktivitas tersebut dilakukan selama rentang masa liburan. Aktivitas tersebut berkaitan dengan pemenuhan kebutuhan fisik seperti berolah raga, menyalurkan hobby seperti melihat kegiatan budaya yang sedang berlangsung, mengikuti kelas spa atau pun mengikuti kelas memasak yang diselenggarakan di hotel tempat wisatawan menginap.

Dengan keadaan lingkungan yang lebih tenang dibandingkan dengan destinasi lain seperti Kuta, Desa Sanur merupakan tempat yang tepat bagi wisatawan lanjut usia untuk melakukan berbagai aktivitas pariwisata yang berkaitan dengan motivasi mereka berlibur.

Aktivitas terkait dengan kebutuhan yang di dorong oleh motivasi fisik wisatawan lanjut usia diantaranya adalah relaksasi, berlari pagi, bersepeda, jalan-jalan dan spa. Kemudian aktivitas lain yang berhubungan dengan pemenuhan hobi dan kesenangan serta di picu oleh motivasi pribadi dan motivasi peningkatan kemampuan diantaranya adalah visiting friends and relatives, mengikuti kelas memasak, berpartisipasi pada kelas yoga, mengikuti kelas spa, membaca, 
seeightseeing, shopping dan menghadiri festival atau kegiatan kebudayaan seperti Sanur Village Festival,Kite Festival yang diselenggarakan secara teratur setiap tahunnya.

Tradisi budaya masyarakat Sanur yang kental dengan seni budaya sangat berpengaruh terhadap proses pemilihan Sanur sebagai daerah tujuan wisata bagi wisatawan lanjut usia. Hal ini dapat dilihat pada bulan-bulan tertentu saat diselenggarakannya festival-festival kebudayaan yang dilaksanakan oleh masyarakat Bali umumnya dan Sanur khususnya, mengikuti kelas memasak (cooking class khusus mengenai masakan tradisional Bali). Wisatawan dalam hal ini wisatawan lanjut usia yang datang untuk menikmati festival kebudayaan ini didorong oleh keinginan untuk meningkatkan aktualisasi diri mengenal dan memahami budaya lain di luar budaya mereka sendiri, menambah wawasan mereka mengenai adat istiadat, tata krama, seni yang ada di daerah yang dikunjungi.

Selain sebagai sarana aktualisasi diri, kegiatan wisata yang dilakukan oleh wisatawan lanjut usia juga merupakan usaha untuk memenuhi kebutuhan fisik seperti berelaksasi, jogging,spa, bersepeda.

\section{SIMPULAN}

Melihat persepsi wisatawan lanjut usia terhadap fasilitas akomodasi yang mendapatkan skor penilaian $89.07 \%$ yang artinya sangat baik menunjukkan bahwa fasilitas akomodasi merupakan fasilitas pariwisata yang diminati oleh wisatawan kelompok umur ini. Fasilitas akomodasi yang paling banyak di pilih adalah akomodasi yang berdesain lokal menyerupai villa atau bungalow yang dapat memberikan suatu kenyamanan baik dari segi suasana kamar, keamanan yang ada di sekitar hotel kemudian keberadaan taman - taman di sekitar bangunan kamar. Penggunaan material lokal juga sangat memberi kesan tradisional yang menjadi daya tarik tersendiri bagi wisatawan lanjut usia. Selain itu minat mereka dalam pemilihan akomodasi ini juga di dasari oleh keterbatasan fisik yang mereka miliki. Semuanya menjadi satu kesatuan yang menyeluruh sehingga wisatawan lanjut usia merasa nyaman karena tidak menemukan kesulitan yang berarti ketika menikmati fasilitas akomodasi. Jarak antara hotel dengan pantai juga tidak terlalu jauh sehingga akan 
memudahkan wisatawan lanjut usia jika ingin melakukan aktivitas di pinggir pantai.

Kemudian dari segi aktivitas pariwisata yang ada sesuai dengan minat wisatawan lanjut usia yang didorong oleh motivasi mereka sendiri untuk meningkatkan aktualisasi diri dengan mempelajari budaya lain yang dimiliki oleh masyarakat lokal dalam hal ini masyarakat Desa Sanur yang sangat memegang teguh nilai-nilai tradisi.

\section{DAFTAR RUJUKAN}

Ardika, Wayan. 2003, Pariwisata Budaya Berkelanjutan; Refleksi dan Harapan di Tengah Perkembangan Global, Denpasar: PS Magister Kajian Pariwisata Universitas Udayana

Butler, R. W. 1996, The Role of Tourism in Cultural Transformation in Developing Countries, dalam Tourism and Culture: Global Civilization in Change, Wiendu Nuryanti (ed), Yogyakarta: Gadjah Mada University Press.

http://www.answers.com/topic/accomodations, 22 Januari 2008, 15: 23 WITA

Keputusan Menteri Kehakiman No. M-04.12.01.02/1998 tentang Pemberian Temporary Visa bagi Wisatawan Lanjut Usia. Menteri Kehakiman dan HAM

Monografi Kelurahan Sanur, 2004, Sanur - Denpasar

Peraturan Daerah ( Perda ) No.4 Tahun 1999 tentang Perubahan Pertama Peraturan Daerah Prop. Daerah Tingkat I Bali No. 4 Tahun 1996 tentang Rencana Tata Ruang Wilayah Propinsi Daerah Tk.I Bali, Gubernur Kepala Dearah Tk. I Bali.

Pitana, I. G. dan Gayatri. 2005, Sosiologi Pariwisata. Yogyakarta : Andi Offset

Smith, V.L. 1997, Introduction To Hosts and Guest : The Antropology of Tourism dalam The Eathscan Reader in Sustainable Tourism, Lesley France (ed). United Kingdom (UK): Earthscan Publication Ltd.

Yoeti, Oka, A. 2001, Pariwisata: Sejarah, Perkembangan dan Prospeknya, Jakarta: PT. Pertja 